\title{
Editorial: Confronting power with laughter
}

\author{
Villy Tsakona \\ Democritus University of Thrace, Greece \\ Diana Elena Popa \\ Dunarea de Jos University of Galati, Romania
}

\section{The story behind this issue}

There is a well-known saying that goes "The criminal always returns to the crime scene" and implies that people (whether criminals or not) return to a place, an act, an experience important to them, either to remember and relive the "good old days" or to commit the same "crime", or both. Remembering and reviving our "criminal" past, we thus return to political humour research after our first edited volume (Tsakona \& Popa 2011b). The first reason for our return was the kind invitation of the organisers of the 2012 ISHS Conference, in Krakow, Poland, to put together a panel on political humour. The second reason was the participants of the panel and their contributions. It seemed that research on political humour continued (and continues) to attract several scholars coming from diverse theoretical and methodological backgrounds and offering new, refreshing insights on the political dimensions of humour. We consider it worth mentioning here that, if our panel at the conference consisted of 12 papers, these papers were less than half of the papers on political humour presented in the whole conference. A close look at the conference schedule reveals that political jokes and cartoons, ethnic humour, political satire, and political entertainment appear to be among the most popular topics currently investigated by humour scholars.

This special issue includes 6 of the papers which were part of the political humour panel in Krakow one year ago. In the present introduction we will try to discuss some recent developments in the analysis of political humour, as brought to the surface by recent publications. We will try to avoid long references to concepts and issues that were extensively discussed in Tsakona \& Popa (2011b), even though some overlapping may eventually be inevitable. Hopefully, the papers included here and the ensuing discussion will allow us to shed some new light on political humour and to open new horizons to future political humour researchers. 


\section{Introducing recent trends in the analysis of political humour: New genres, reception, and context}

In order to compile a working definition of political humour, it seems that its content needs to be taken into consideration: political humour pertains to political issues, namely political acts and decisions, policies, politicians, political debates, power inequalities, etc. It is produced either by politicians or by cartoonists, journalists, media personas, and citizens, usually in public but also in private settings (see Ritchie 2011). Contemporary political humour owes much of its popularity to the media: most of the genres belonging to (or including) political humour are produced and/or disseminated via the media (e.g. political jokes and cartoons, satirical shows and webpages, political advertisements). Even when such humour surfaces in non prototypical humorous contexts (e.g. political or parliamentary debates, political interviews, news reports, slogans, graffiti), it is often (re)framed and reinterpreted by the media.

The significant role the media plays in the production and transmission of humorous messages is highlighted by the development of new genres including (political or other) humour. Internet memes is one of the most popular and worth-examining genres. Memes include images, videos, audios, or hyperlinks with humorous content, which are created by individuals with online access and easy-to-use software. Such material is very quickly and easily produced and circulated via online social networks, thus allowing individuals to offer their (humorous or not) creative perceptions and comments on current (political or other) events (Avidar 2012, Chen this issue). Furthermore, the media offers publicity to public political protests and/or stunts which may exploit humour for their purposes. As a result, the audience are informed not only on what activists and grassroots organisations think about a variety of social, political, ecological, etc. issues, but they can also witness on their (TV, computer, mobile phone) screens how they express their views and protest against state, corporate, etc. decisions and policies (see Sørensen this issue, and references therein). Contrary to more traditional and institutionalised forms of political humour, internet memes and political stunts could be classified as unconventional political humour, since it appears that citizens are the main creators and participants in such genres, while state or media control is relatively more limited or less conspicuous.

On the other hand, given that the media provides ample access to political settings and institutions (e.g. political conferences and debates, public speeches, parliaments), which was denied to citizens some decades ago, it has become the main arena of political debate and conflict (Bayley 2004: 11, Fetzer \& Lauerbach 2007). Politicians are most aware of this, hence their discourse is aimed at influencing and impressing the wider audience. In other words, they know in advance that what they are about to say in specific settings or events covered by the media will most probably be heard by their prospective voters. The humour produced by politicians has to be accounted for in these terms, that is, as a way to please the wider audience and make them laugh (often at the expense of their adversaries), thus constructing a widely disseminated positive self-image. This is why politicians are often recorded to recite jokes (Shilikhina this issue), use punning (Tsakona this issue), humorous narratives, or other forms of humour in their public appearances or even in highly institutionalised contexts such as the parliament (see Archakis \& Tsakona 2011, Dynel 2011, Georgalidou 2011, Mueller 2011, Yoong 2012, and references therein). Thus, humour becomes a political marketing tool and a prominent part of the media spectacle (Attardo 2012). 
So far, the majority of studies in political humour have concentrated on its goals, functions, and meanings as perceived and interpreted by the researchers themselves. In other words, following the relevant practices in pragmatics and discourse analysis, the analysis of political humour more often than not reflects what researchers think the producers of political humour mean and intend to say. Such analyses are based on the oral and written details of the humorous message which are usually connected with the immediate or wider sociopolitical context, where the message is produced and (potentially) circulated. It is more recently that humour scholars have started to investigate what recipients themselves make out of political humour, namely how they interpret and evaluate such messages. In Stewart's (2013: 200) terms, scholars have recently started to perform a "reader-centred analysis [...] investigating not only the artifact for the various potential meanings that might be recovered from it but also discursive evidence for the ways that the image was actually interpreted" (our emphasis).

This line of research has already yielded some interesting results which shed light on the various audience perceptions and reactions to political humour (see El Refaie 2011, Kramer 2011, Laineste 2011, Stewart 2013, Tsakona to appear, Moreno this volume, and references therein). It seems that the intention of the humorist does not always reach his/her audience: recipients' ideologies on what humour is, what can be joked about, how a humorous message is expected to be (re)framed, structured, and designed, when and by whom humour is to be produced, and the ways recipients position themselves towards the targets of humour, may all turn out to be equally (if not more) important than the humorist's intent in the understanding and appreciation of political humour. Furthermore, the social characteristics of recipients (e.g. ethnicity, place of origin/residence, political affiliation/positioning) as well as their previous experience with other texts and the background knowledge they (need to) resort to in order to understand political humour emerge as significant parameters influencing how it is perceived and evaluated (Braun \& Preiser 2013, Stewart 2013, Tsakona to appear, Moreno this issue, Pinar this issue).

In other words, such studies have started to address the sociocultural differences in, and preferences for, humour production and appreciation, thus leaving behind more traditionally shaped, essentialist studies investigating "universal" topics and targets in humour practices or considering specific humorous texts as potentially funny to "all" recipients. Central to this turn in the analysis of political humour is the importance attached to context as a parameter shaping its production and interpretation. Its meanings cannot be arrived at, and accounted for, without taking into consideration that political humour circulates in specific social settings, is produced by specific speakers/writers, and directed at specific addressees, who live in specific places at specific times and do not share the same views on a variety of sociopolitical issues (Hill 1995, El Refaie 2011, Popa \& Tsakona 2011: 273-274, Stewart 2013, Tsakona to appear).

\section{The content of the special issue}

This special issue begins with two studies focusing on the perception of humour. First, Pinar investigates the interplay between, on the one hand, the humorous meanings and the information encoded in political billboards and, on the other, recipients' assumptions and the knowledge required for the interpretation of such texts. Her analysis exploits Sperber \& Wilson's (1995) relevance theory and Attardo's (1994) incongruity-resolution theory in 
combination with concepts and insights coming from multimodal metaphor analysis. This framework allows her to underline the importance of specific sociocultural knowledge for the decoding of the humour of political billboards. Moreover, she explores the possibility of different meanings and interpretations derived from a single text, depending on recipients' diverse sociopolitical identities, as well as the possibility of the failure of some recipients in reaching any interpretation at all. Her contribution is important not only for humour analysts but also for politicians and spin doctors who may not always realise (at least not in advance) the implications and multiple potential of their campaign material, which may eventually not come across the way they designed it to.

Moreno also discusses humour reception but from a different perspective, with different methodology, and in an intensely diverse sociocultural context where the issue of national and ethnic identities is far from resolved. His focus is on ethnic humour in Spain, as he examines the reactions to two humorous sketches from TV shows, one coming from the Basque Country and one from Catalonia. These sketches are evaluated as to their funniness by informants coming from different regions of Spain. This study shows that the appreciation of ethnic humour in Spain correlates with social variables such as the place of origin/residence of the informants, its distance from the Basque Country and Catalonia (where the sketches were produced and aired), the informants' prior experiences with satirical TV humour, and their attitudes towards the targeted ethnic group. It also correlates with the content of the humorous sketches, in particular with the targets of humour as well as with its perceived political intentions or messages. The importance of this study lies in the fact that it brings to the surface new kinds of ethnic humour (besides the well-known stupidity or canniness jokes) emerging in the media and contributing to the recycling of ethnic stereotypes in Spain. It also reveals that ethnic humour may not be unanimously accepted by all the citizens of a state, but instead different reactions and interpretations may be elicited by informants belonging to different ethnic groups.

We now move on to forms of unconventional political humour, which, as already mentioned (in Section 2), allow for citizen participation in their production and dissemination. Chen presents a case study from Singapore, where press freedom is limited (at least compared to Western countries), thus the articulation of dissent has not been common practice. In such a context, a breakdown of the transportation system triggered a chain of citizen reactions, especially on the internet, in the form of memes (see Section 2), which humorously attacked the person considered accountable for the breakdown. The author describes in detail how Singaporeans humorously reframed the problems they experienced in their transportation, in order to protest against the authorities' inadequacy and indifference to provide immediate solutions. The humour produced and circulated online became a significant part of the expression of public discontent which resulted in the resignation of the official targeted as responsible for, and incapable of, dealing with the malfunction. Chen offers one of the rare cases in political humour literature, where humour seems to have an effect (albeit a limited or indirect one) on political reality (see also Popa 2011). Even though it did not lead to a radical change in the political regime, such humour enabled citizens to quickly and aggressively react to the unpleasant situation they were faced with, and to protest in a state where censorship and intimidation rule(d). Hence, this study highlights the role digital media plays nowadays in enabling citizens to express their political views via new genres, and perhaps in accelerating specific political decisions and events.

Citizens' reactions not via the net but in the form of humorous activism are the topic of Sørensen's study. Her analysis reveals how grassroots organisations employ various forms of humour to denigrate and delegitimise their targets and to challenge state or other authorities. 
The data examined comes from different sociocultural environments and involves various types of events and protests, which are classified in 5 categories: supportive, corrective, naive, absurd, and provocative. Political stunts exploit humour in their effort to embarrass their targets, and more often than not they succeed in it. Most importantly, they manage to attract audience attention and inform them on the political issues or problems they protest against by pointing out the inconsistencies and absurdities of the status quo. However, their effect seems to be a short-term one, since, like other forms of political humour, there seems to be no record of a major political change resulting from this kind of protests. In any case, the contribution of Sørensen's study is significant, since it expands the analysis of political humour to previously unexplored (con)texts, while it also offers interesting insights into the ways activists design their protests and employ humour to attain their goals.

The two final papers of this special issue are dedicated to humour produced by politicians and referring to them. Shilikhina even takes us back to political humour basics: political jokes. Unlike most previous studies on political jokes, the author offers a contextualised analysis of them: they are presented and discussed as used and recycled by real people, namely Russian politicians and media people, in real contexts, namely in their speeches and public appearances. Their meaning, as she suggests, is shaped by the particularities of the context of their use, and their targets are not necessarily (or exclusively) the joke characters, but may be the teller's addressee(s) or other "real" people. Such recontextualised jokes eventually convey serious messages concerning contemporary political affairs. In this context, Shilikhina discusses the limits of the non bona-fide mode of communication (Raskin 1985). Although jokes are supposed to belong to this mode, where nothing accurate, sincere, or truthful is expected, in their contextualised use and analysis this cannot be maintained: jokes do convey serious comments and messages about politics and become a symbolic weapon in politicians' struggle for power. Hence, this study underlines the importance of context for the interpretation of political jokes as well as their evaluative dimension, which may not necessarily refer to the persons, actions, and places described in the joke-texts, but may pertain to contemporary political environments.

The final paper is on parliamentary humour, in particular on the use of puns in the Greek parliament. Tsakona attempts to correlate the use of punning with the institutional particularities of the Greek parliament and the antagonistic discursive practices emerging therein. The data examined comes from a no-confidence parliamentary debate where the then most important political issues were hotly debated between the members of the government and the ruling party, on the one hand, and the opposition parties, on the other. Like most forms of humour, punning in this context appears to be multifunctional as it is employed by parliamentarians to serve 3 different goals (denigration, challenge, and support), all related to their institutional roles. Denigration emerges as the prevalent function of parliamentary punning, which, as the author suggests, may be related to the aggression of the debate and to the fact that most of the puns come from the major opposition party which launched the debate against the government. Hence, once again, the wider institutional and the local, discourse context plays an important role in determining how humour is to be used and interpreted.

The above studies confirm what Westwood \& Johnston (2013: 229) call "the ambiguous and paradoxical nature of humour as both a contestive device and as a way of sustaining social hierarchy", in the sense that it allows criticism and tension to be linguistically encoded and released, but without usually jeopardising the safety of the targeted persons and the 
stability of the attacked state or other institutions. In other words, humour constitutes a form of permitted disrespect (Radcliffe-Brown 1952; see also Seirlis 2011: 526-529). The fact that, when we produce (political or other) humour, we are more often than not perceived as "non serious" and "inconsequential" seems to heighten our own sense of freedom in the way we express ourselves. This, however, does not mean that what is humorously encoded is totally devoid of a serious intent or that it does not reflect a specific positioning towards real people and real situations. If this were the case, all research on the meanings, functions, and effects of (political) humour would be pointless (cf. Tsakona \& Popa 2011a: 9-16).

Furthermore, the present collection of essays attests to the variety of methodological approaches and data subsumed under the analysis of political humour. It seems that today political humour surfaces in more numerous and more diverse contexts and genres, thus attracting the attention of scholars subscribing to different disciplines and traditions. Hence, this issue offers only a snapshot of contemporary trends and directions in the field, allowing us to anticipate more and fascinating studies to materialise in the future.

\section{Connecting political humour with political discourse}

Rounding up the present discussion, we would like to explore some parallels between the analysis of political discourse and that of political humour. As suggested by Fairclough \& Fairclough (2012: 17-21), the majority of studies in political discourse have so far concentrated on the representation of political reality, namely on how discourse is used to offer an account of the past or current state of political affairs or to propose alternative conceptualisations of political reality to be attained in the future. Although such representations are a prerequisite for any kind of political decision and action, the relevant studies have neglected the analysis of political discourse as a tool of decision-making and political action. Hence, Fairclough \& Fairclough (2012) propose an alternative theoretical framework in their attempt to argue for a turn from the analysis of the representative function and potential of political discourse to the analysis of its practical use in order to achieve actual effects; that is, how discourse is employed to perform political actions, implement political decisions, and eventually induce political change.

If we recontextualise this proposal to the analysis of political humour, some interesting in our view- questions and issues arise. First of all, it cannot be denied that, like the analysis of political discourse, the analysis of political humour has predominantly concentrated on how humour is used to represent political reality, to humorously account for it, and to offer (more or less incongruous) alternatives. This is an important common trait between the two fields, confirmed by all the papers included in the present special issue (as well as by the essays included in Tsakona \& Popa 2011b).

Could, however, the analysis of political humour turn to how and when humour is or could be used to implement policies and create new political contexts? One answer to this question may be obvious and easy to (political) humour researchers: the ambiguity and the non serious nature of humour would prevent it from becoming part of (con)texts where "serious" political discourse prevails and is meant to perform specific actions, for example, in laws, constitutions, decrees, stipulations, political agreements, pacts, treaties, etc.

Nonetheless, we would like to take this line of thought a step further, so as to exploit and highlight political humour's critical and creative potential. It has already been suggested that one of the most significant motives behind political humour is to challenge the status quo and allow for creative conceptualisations of political affairs (the other one being to reinforce 
it; see Tsakona \& Popa 2011b, Chen this volume, Shilikhina this volume, Sørensen this volume, and references therein). Under this capacity, political humour could become part of imaginaries, namely "discursive (semiotic) representations of a possible, non-actual (or notyet-actual) world", "capable of guiding [political] action", since they "give people reasons for actions" (Fairclough \& Fairclough 2012: 103, 104; emphasis in the original). Hence, research could investigate whether political humour is used or it could be used as the basis for deliberating and designing new policies: if political humour, as already demonstrated, is not totally devoid of serious messages and criticism, more importance could be attached to its messages by politicians and citizens in their quest for new ideas and creative solutions to political problems. To be more specific, the ideas expressed via humour in a variety of contexts and genres could be worth pondering on and deliberating in an effort to reach solutions to political problems as well as alternatives to political actions. In this sense, political humour, after and besides making us laugh, could incite or even force us to see things from a different perspective.

In this context, we would like to suggest that the analysis of political humour could bring to the spotlight how the criticism and alternatives transmitted via political humour could enable citizens and politicians to change the political landscape and the ways they handle political issues. Up to now, the messages conveyed via political humour are usually dismissed and/or "merely laughed at/with": their entertaining dimension prevails as people seem to concentrate on the "funny" representation of political reality. But what about the critical and alternative aspects of political humour? Scientific and, in general, public deliberation on ideas and stances put forward via political humour could make people (more) aware of a variety of political problems and to incite them to reflect and deliberate on potential solutions. It could also render them more capable of identifying the ideologies lurking behind specific humorous texts, and foster a more reflexive and critical stance towards them. In short, if political humour carries serious messages, such messages need not remain critically unexplored. Political humour could thus become a "reason for action", as Fairclough \& Fairclough (2012: 104) put it, and could contribute to political change.

Back to Fairclough \& Fairclough (2012: 235-236) who suggest the following:

In contemporary political theory, but also in Aristotle, politics is defined in terms of such concepts as deliberation, decision and action, and the context in which politics operates is said to be one of disagreement (including irreducible conflicts of values and interests), incomplete information and uncertainty as to what the right course of action might be (hence, risk), urgency, as well as other constraints. It is also a context in which the possibilities for democratic deliberation and political participation are often limited by people's unequal access to resources, by power inequalities and by the institutional complexity of modern societies.

Most analyses of political humour agree that it is definitely part of the public "deliberation" on political issues. It is a vehicle for "disagreement" expressing "conflicts of values and interests", especially when there seems to be "uncertainty as to what the right course of action might be (hence, risk), urgency, as well as other constraints". It also allows for citizens' "political participation", even if it is "limited by people's unequal access to resources, by power inequalities and by the institutional complexity of modern societies". Hence, political humour could constitute a part of political discourse which would offer new, alternative perspectives on politics, by becoming the object of political deliberation and, hence, the basis for political "decision and action". 


\section{Acknowledgments}

We would like to thank the anonymous reviews for their assistance in the preparation of this special issue, as well as Argiris Archakis for his helpful suggestions on this editorial. We would also like to thank the contributors of this special issue for their eagerness to be part of it, their hard work, and their collaboration, as well as the organisers of the 2012 ISHS Conference who incited us to hold the political humour panel, thus giving us the opportunity to meet new political humour researchers and share our interests. Returning to the political humour "crime scene" has been an honour but, most of all, a pleasure. Let's do it again some time!

Correspondence e-mail addresses: villytsa@otenet.gr and dpopa@ugal.ro

\section{References}

Archakis, A. \& Tsakona, V. (2011). 'Informal talk in formal settings: Humorous narratives in Greek parliamentary debates,' in Tsakona, V. \& Popa, D. E. (eds.), Studies in Political Humour: In between Political Critique and Public Entertainment. Amsterdam \& Philadelphia: John Benjamins, pp. 61-81.

Attardo, S. (1994). Linguistic Theories of Humour. Berlin \& New York: Mouton de Gruyter.

Attardo, S. (2012). 'Political humour, senselessness, and pragmatic irresponsibility.' Paper presented at the 2nd International Conference on Humour in Conventional and Unconventional Politics (ICHCUP), Dunarea de Jos University, Galaţi, Romania, 5-8 November.

Avidar, R. (2012). 'How a politician can successfully use self-humour and apply public relations principles online: An Israeli case study.' Israeli Journal of Humour Research, 1 (2), pp. 81-96.

Bayley, P. (2004). 'Introduction. The whys and wherefores of analysing parliamentary discourse,' in Bayley, P. (ed.), Cross Cultural Perspectives on Parliamentary Discourse. Amsterdam \& Philadelphia: John Benjamins, pp. 1-44.

Braun, A. \& Preiser, S. (2013). 'The impact of disparaging humour content on the funniness of political jokes.' Humour: International Journal of Humour Research, 26 (2), pp. 249-275.

Dynel, M. (2011). 'Entertaining and enraging: The functions of verbal violence in broadcast political debates,' in Tsakona, V. \& Popa, D. E. (eds.), Studies in Political Humour: In between Political Critique and Public Entertainment. Amsterdam \& Philadelphia: John Benjamins, pp. 109-133.

El Refaie, E. (2011). 'The pragmatics of humour reception: Young people's responses to a newspaper cartoon.' Humour: International Journal of Humour Research, 24 (1), pp. 87-108.

Fairclough, I. \& Fairclough, N. (2012). Political Discourse Analysis. A Method for Advanced Students. London \& New York: Routledge.

Fetzer, A. \& Lauerbach, G. E. (eds.) (2007). Political Discourse in the Media. Amsterdam \& Philadelphia: John Benjamins.

Georgalidou, M. (2011). "Stop caressing the ears of the hooded": Political humour in times of conflict,' in Tsakona, V. \& Popa, D. E. (eds.), Studies in Political Humour: In between Political Critique and Public Entertainment. Amsterdam \& Philadelphia: John Benjamins, pp. 83-107.

Hill, J. H. (1995). 'Junk Spanish, covert racism, and the (leaky) boundary between public and private spheres.' Pragmatics, 5 (2), pp. 197-212.

Kramer, E. (2011). 'The playful is political: The metapragmatics of internet rape-joke arguments.' Language in Society, 40 (2), pp. 137-168.

Laineste, L. (2011). 'Politics of taste in a post-Socialist state: A case study,' in Tsakona, V. \& Popa, D. E. (eds.), Studies in Political Humour: In between Political Critique and Public Entertainment. Amsterdam \& Philadelphia: John Benjamins, pp. 217-241. 
Mueller, R. (2011). 'Fun in the German parliament?,' in Tsakona, V. \& Popa, D. E. (eds.), Studies in Political Humour: In between Political Critique and Public Entertainment. Amsterdam \& Philadelphia: John Benjamins, pp. 33-59.

Popa, D. E. (2011). 'Political satire dies last: A study on democracy, opinion formation, and political satire,' in Tsakona, V. \& Popa, D. E. (eds.), Studies in Political Humour: In between Political Critique and Public Entertainment. Amsterdam \& Philadelphia: John Benjamins, pp. 137-165.

Radcliffe-Brown, A. (1952). Structure and Function in a Primitive Society. London: Cohen \& West.

Raskin, V. 1985. Semantic Mechanisms of Humour. Dordrecht: D. Reidel.

Ritchie, L. D. (2011). "You're lying to Jesus!": Humour and play in a discussion about homelessness.' Humour: International Journal of Humour Research, 24 (4), pp. 481-511.

Seirlis, J. K. (2011). 'Laughing all the way to freedom?: Contemporary stand-up comedy and democracy in South Africa.' Humour: International Journal of Humour Research, 24 (4), pp. $513-$ 530.

Sperber, D. \& Wilson, D. (1995). Relevance: Communication and Cognition, $2^{\text {nd }}$ expanded ed. Oxford: Blackwell.

Stewart, C. O. (2013). 'Strategies of verbal irony in visual satire: Reading The New Yorker's "Politics of Fear" cover.' Humour: International Journal of Humour Research, 26 (2), pp. 197-217.

Tsakona, V. (to appear). 'Okras and the metapragmatic stereotypes of humour: Towards an expansion of the GTVH,' in Dynel, M. (ed.), Developments in Linguistic Humour Theory. Amsterdam \& Philadelphia: John Benjamins.

Tsakona, V. \& Popa, D. E. (2011a). 'Humour in politics and the politics of humour: An introduction,' in Tsakona, V. \& Popa, D. E. (eds.), Studies in Political Humour: In between Political Critique and Public Entertainment. Amsterdam \& Philadelphia: John Benjamins, pp. 1-30.

Tsakona, V. \& Popa, D. E. (eds.) (2011b). Studies in Political Humor: In between Political Critique and Public Entertainment. Amsterdam \& Philadelphia: John Benjamins.

Westwood, R. I. \& Johnston, A. (2013). 'Humour in organisation: From function to resistance.' Humour: International Journal of Humour Research, 26 (2), pp. 219-247.

Yoong, D. (2012). 'The case of humour in the Malaysian House of Representatives.' Humour: International Journal of Humour Research, 25 (3), 263-283. 